\title{
Oganihu Ndiigbo: Through the Social-Existential Forces of Ikeoha and Ikeotuonye
}

\author{
Chika J.B.G. Okpalike \\ http://dx.doi./org/10.4314/ujah.v18i3.3
}

\begin{abstract}
'Oganihu Ndiigbo' is an ontological drive in being Igbo. The survival and sustenance of the race have been the pre-occupation of every Igbo generation from time immemorial. In ancient times, this drive is expressed in its microcosmic form in the various interclan clashes and boundary disputes aimed at preserving the parochial city-states which had little or no socio-political connection with each other. With the colonial arrangements, this microcosmic consciousness bloomed into a pan-Igbo drive for the social welfare of Ndiigbo. The post-war Igbo experience brought forth yet another dimension of this existential character of the Igbo which could be seen in what Eteng (2002) referred to as "selfhelp". Many Igbo communities lived and provided social amenities and good governance for their people like there was no government. This article traces two moments of the social forces of Ikeoha and Ikeotuonye in the Igbo trajectory towards Oganihu Ndiigbo and proffers ways of harnessing them.
\end{abstract}

\section{Introduction}

Ndiigbo refers to Africans of Igbo extraction; it is also one of the major tribes of Nigeria alongside Hausa and Yoruba. They are scattered all over the world and are heavily concentrated in the South-Eastern part of Nigeria. Many scholars of Igbo studies subscribe to the Jewish origin of Ndiigbo (Rosen 2002, Ilona 2007, 
Abasika 1993, Madu 2012). This work does not focus on affirming or negating whether this claim is true or not. Yet it is important to note that the same predicament suffered by the Israeli nation among their Arab brothers is experienced by the Igbo among other Nigerian tribes (Adujie 2011); another similarity that could be drawn between the Jews and Ndiigbo.

Evidently there exist phobia and suspicion for Ndiigbo among other tribes of Nigeria. For some, this fear and suspicion is an Igbo chimerical fancy and delusion (Osuji, 2008) and for others it exists but Ndiigbo are to be blamed for it. Corroborating this last opinion, Kolawole (2011) came up with the double theory of "Conspiracy" and "Enemy-within". Kolawole's theories were generated in his bid to analyze the Nigerian political situation; the stake and chances of Ndiigbo in the 2015 presidential race. As at the time of this article, Ndiigbo have settled for the candidature of Dr. Goodluck Ebele Jonathan who (by geographical definition) is not Igbo but cannot deny Igbo descent completely. However that may be, if Ndiigbo are faced with a political war, they may employ other weapons open to it to fight it.

On the contrary, the challenges of the present-day Ndiigbo are multi-facetted. This writer is agitated by the various dimensions of Igbo challenges - moral, religious, educational, cultural, political and environmental. The work employs two concepts "Ikeoha" and "Ikeotuonye" to represent the existential forces which drove and interpreted the life of Ndiigbo in two broad epochs - the first spanning from immemorial times to the period of Nigerian civil war and the second from after that war till the present times. In doing this, this writer agrees with the common opinion among Ndiigbo that the aftermaths of the war play out in every dimension of the Igbo life. The first epoch is characterized by the existential force of 'Ikeoha'. Ikeoha is in conformity with 
communalist ethos. This force held sway in a society where every individual identifies himself/herself as a part of the living community of corporeal and disembodied human entities. The individual has no self-determination; he or she lives to service the real life which is the life of the community (Uzukwu, 1996). The quest and desire to live and to make something out of life is informed by the strength of ties that bonds one with the community reckoned in degrees of relationship.

On the other hand, Ikeotuonye is in conformity with an individualist ethos which has been acquired by Ndiigbo through the years of interaction with the western world and unwholesome experiences in the Nigerian socio-political equation. This form of consciousness drives the individual Igbo person to keep his/her track on the way to success and progress as if he/she cared nothing about the Igbo as a race. It is this acquired character of Ndiigbo that has worried so many, which forms the background to the understanding of Kolawole's agitation and the typical understanding of an average Igbo whenever the issues of Igbo socio-political situation in Nigeria is discussed. It should be noted, however, that the Igbo race is a spiritual, moral, social, political and economic community which takes together the past, present and future; the living and the dead members of the constituent people and who think of themselves as special species of the human race.

This article goes through the ambient of the lived experiences of Ndiigbo abstracting these two concepts and using them to analyze the historical, sociological, political and economic situation of the people in such a way that either of them still serves the same living quest and pan-Igbo consciousness - Oganihu. It examines the social consciousness that connected the Igbo to Oganihu Ndiigbo in the different epochs of Igbo historical 
development. However, suffice it to say from the on-set that as much as the social consciousness examined would appear opposing, they are not contradicting of that Pan-Igbo existential drive of Oganihu Ndiigbo as would be made clear later in the work.

\section{The Concept of Social-Existential Force and its Igbo (African) Version}

It was the Belgian missionary, Placide Tempels, who expressed "Being" in terms of force. In his La Philosphie Bantou, Tempels impressed that for this African people "being is force and force is being". It is important to note that this force is not a mechanical entity as will be understood by western science which "differentiates "being" by their essences or natures, and separates "Being" from force, with the latter as its attribute" (Ekwuru, 1999). Tempels meant that force is the nature and essence of being.

The African world is a manifestation of this force and everything in the world embodies this force as such. This force is life itself. Therefore, it could be said that in Africa nothing is dead; everything is living and is capable of motion. In a special way, human beings are highest manifestation of the force; they both embody this force, control and use it to manipulate other things in the world. Odimegwu (2007) averred that "force is characterized by revolutionary impulsion and is intended for action which is both negative and positive" (p. 215). This is to say that everything that is part of the African concrete environment is constituted of and impregnated by this force and is fully potentiated to movement; being effectively part of that living environment.

However, it is important to note the origin of conceptual existentialism. Existentialist philosophers of Europe between $19^{\text {th }}$ 
and $20^{\text {th }}$ centuries expressed concerns about human conditions within an ontology which has diverse methods and thematic differences. In other words, human existence in the period was subjected to a variety of rational movements and orientations represented by philosophers of that period of history. Themes like anxiety, anguish, fear, authenticity, freedom and so forth could be found in the works of philosophers like Søren Kierkegaard, Fredrick Nietzsche, Albert Camus, Martin Heidegger, Jean Paul Sartre and so forth.

Nevertheless, existentialism in Africa is not a matter of theorizing or idealizing, it is a narrative from real experiences. According to Onwubiko (1991),

In real life situations, African ideas of life, man, and the universe are also dependent on practical experiences through the ages as communities ... African ideology must be understood in terms of the African experience; because the realities of life must be understood in terms of existential postulates and explained in specific normative African concepts (p. 4).

It is important to note this advocacy of Onwubiko that the African experiences can most aptly be explained in specific African concepts. However, the nature of existentialism even in its European cast, agrees with the pattern of making out concepts from concrete experiences. For Africans then, it is not fossilized, immobilized and isolated concepts but a life dynamo that is everywhere and every time causing motion and generating life. So, when this writer referred to Oganihu Ndiigbo as an existential force, he is abstracting a living concept from Igbo concrete experiences through history. This concept in as much as it is an ontological expression of the concrete experiences of Ndiigbo, is 
also a consciousness; an Igbo ontological consciousness. To put it straight, the force, consciousness or drive behind all the efforts, struggles and contributions of Ndiigbo in the sphere of human existence is Oganihu Ndiigbo. For every Igbo-bu-Igbo (bonafide Igbo) this does not mean that the life of Ndiigbo is valued above the lives of other peoples and races in such a way that the Igbo look down on them or that Ndiigbo focused on their independent tribal affairs excluding or caring nothing about the rest of humanity, but that Oganihu Ndiigbo is the springboard of global or universal development and progress (Ezeani, 2013).

For this reason, Ndiigbo do not hesitate to settle down in whatever part of the world where human beings live; defying any degree of environmental threat. This settling down is not in the manner of a parasite on prey but in a manner of a symbiosis that most times makes a hybrid of such Ndiigbo. It is common to see Diaspora Igbo assimilating the language, culture and philosophy of the people and environment where they live to the detriment or even spitefulness of their Igbo equivalents; making themselves integral part of that foreign land and virile agents of its development. In order to achieve the development of any environment where Ndiigbo find themselves, they must first of all pull themselves together to institute a union which serves as forum to energize this existential force.

The most important reason for coming together in that union from time to time is to enliven that Igbo existential consciousness which could also bear on the foreign land to develop it and to develop that unique synergy which is peculiarly Igbo to drive that development beyond the immediate generating environment to their South-Eastern Nigerian home fully conscious of those Igbo adages like: "Akuruoulo, a maraonyekpataraya" (It is only at the home front that any wealth made abroad could 
assume its proper identity), "Akpaanambaerienambabuisiiberibe" (Making wealth abroad and spending all thereof is the height of foolery) and so on. Furthermore, the union is the space for the construction of the springboard of global development. There the jingle of "Igbo Kwenu" or any of its variations resounds as a mantra of empowerment full of energy permeating and awakening the body and spirit of all who hear it. Onunwa (2005) referred to this jingle as greeting:

The content of this greeting is a reflection of Igbo philosophical conception of the universe, their aspiration of solidarity, unity and progress as a people. A powerful speaker with tremendous oratorical skill usually arouses the spirit of nationalism and solidarity in any Igbo assembly with this type of greeting. He receives a deafening ovation and applause of 'Yaa" meaning 'we support', 'we agree' etc (p. 6).

More than greeting, Igbo kwenu is a creed or confirmation/seal of an agreement and consensus in a cause of action; it is a call to awaken the Igbo spirit in a perceived listener to focus on the common good, ideal morals and unbroken chain of relationship even beyond the human domain of the Igbo people while using ones individual mind to make judgment. Meanwhile, the platform of Igbo unions is also used to create in foreign lands the same kinds of communities from where the Diaspora may have originally emanated and in such communities the ontological unity of Ndiigbo, which the colonialists and other ethnic groups in Nigeria failed to see, is demonstrated. An old Igbo adage bears the burden of this truth: "Igbo na-asun'olun'olu, mana ha kwaaukwara, oburuofu" (The Igbo express themselves in different dialects but when they come together, even a sigh conveys 
meaning to everyone). This proverb carries the dialectics of parochialism and globalism; particularity and universality which for Ndiigbo is not opposition or contradiction but necessary complementarities. Whereas Ndiigbo may live in very small and independent communities (as in pre-colonial times) or come from different communities to form a common community of Igbo union (as in Diaspora), there is a Pan-Igbo consciousness that could be visible and tangible in their relationship with one another which at the same time is planted in the innermost core of every Igbo person, that consciousness is Oganihu Ndiigbo; an existential force.

\section{The Trajectory of Oganihu Ndiigbo Consciousness in every Igbo-bu-Igbo}

Oganihu is a concept in Igbo that appears futuristic; progressive and on-going. However, beyond that, it also pertains both to past, future and present time. In the past it has to do with traditional trends and institutions that initiated and enhanced it, in the present it has to do with sustenance and maintenance of it; in the future it has to do with furtherance and perpetuation of it. The word can also be rendered as 'Progress', 'enhancement', 'improvement' or 'welfare' depending on the context of usage or in one instance taking together all those ideas in a stride.

Within the framework of this article, Oganihu Ndiigbo is, therefore, the trajectory of an existential Igbo consciousness from the traditional trends and institutions that initiated and enhanced this consciousness, through its maintenance and sustenance, to the furtherance and perpetuation of it and ultimately the Igbo race. Oganihu Ndiigbo is both old and new at the same time since it is at the basis of Igbo existence; it is the ontological drive of the 
undying Igbo-consciousness. Oganihu Ndiigbo is one consciousness to which every "Igbo-bu-Igbo" is connected with passion. In various Igbo communities, this consciousness has resonated as 'Onyeaghananwanneya' (Let no one be left behind in the race of life), 'Ibuanyidanda' (No burden is impossible for danda, the ant), 'Anyiga-adi ka echi', (We shall be like neverending ever-new tomorrow), 'Ebeonye bi ka o na-awachi' (Wherever you live there you care for) and so forth. These are pithy-sayings/slogans with which this consciousness has been enlivened and sustained in various Igbo communities through the years. However, the consciousness of Oganihu Ndiigbo has changed its mode of expression in accordance with varying Igbo experiences through time.

\section{Ikeoha Social-Existential Force}

The word Ikeoha derives from two Igbo words 'Ike' (Force) and 'Oha' (Community). Every one of the hundreds of the individual communities that make up Igbo land could be referred to as Oha; each in the context of its parochial boundaries. The couplet 'Ohanaeze' represents the totality of such a community. No one can really tell how the various small groups and institutions that make up individual communities came to be, but each of them saw Ndiigbo from the prism of their own micro world. Every community has peculiar story of origins; sometimes in the form of myth.

Some of the myths of origins even present the local community that generated them as archetype or prototype of the Igbo race; told in seeming ignorance of the existence of other communities. Such a community, though a few hundred may make it up and sometimes negligible compared to the population of the whole Igbo race, understands itself as Igbo. The totality of the Igbo 
race is often referred to as Oru na Igbo and not Oha na Eze. Be that as it may, the word "Oha" connotes the people be it in a micro or macro sense. The supremacy of Oha among Ndiigbo can be seen in the various traditional social institutions, rites of passage, proverbs, pithy sayings and so forth. This is true for every parochial Igbo community and the origins of these are in the immemorial past. Every elder Igbo person from whom one may want to investigate the origins would most likely retort "that is the way we saw it growing up; my father did it, my grandfather did it too and now it is my turn to do it". Apparently, the Igbo person is swallowed up by Oha yet the egalitarian and competitive environment keeps him/her in the struggle of life.

Odimegwu (2007) had understood the African person as force: "African personhood is not merely a concept but also a force" (p. 215). In traditional African-Igbo society, 'Person' is defined in terms of the community; it is the community that is the existential person and the ontological expression of individual existence. Existential force resides in and with the community. As a matter of fact, the individual person exists like he/she is the community because the community is the person de Jure. It was Okolo (1993) who explained this existence as 'being-with':

In sum, the African as a being-with is simply his tendency to stick together as a member of a family, with its roots in the extended family system. It means feeling-involvedwith-others, participatory living (p. 12).

Even in ordinary day to day encounter, when matured Igbo are asked "Kedu?" (How are you?), they readily answer "Anyi di $m m a "$ (we are fine). The African naturally grows into the Weconsciousness. Onyewuenyi (2002) underscores this point: "In practical terms, this is borne out by the old woman's claim, in 
Chinua Achebe's No Longer at Ease, that the graduate Okonkwo's motor car, is "our" car" (p. 418). Various other authors have identified this socio-ethical disposition of Ndiigbo and indeed Africa as Communalism. Articulating the communalist understanding of the person, Odimegwu (2007) underscored it as "the unity of altruistic relations" (p. 201). The individuality of Ndiigbo is not fundamentally a self-centered individuality; it is a community-oriented individuality. Names like Umunnabuike (the kindred is force), Azubuike (solidarity is force), Igwebuike (the mass is force) and so forth go a long way to locate existential force in the community. Every individual Igbo like other Africans lives and works for the maintenance and sustenance of the community. In achieving this, Ndiigbo naturally create a web of community action in which everybody is connected to and involved with everyone. The Igbo naturally lean on each other for support. Writing about Africa, Ezenweke and Nwadialor (2013) captured the internal working of the community thus:

It is said in Africa that the prosperity of a single person does not make a town rich, but the prosperity of the town makes persons rich. It is not considered repugnant to ask one's neighbour for help if one is struggling to make ends meet. In almost all instances, there was help between individuals, tribes, and communities, e.t.c. even in spite of war. This again explains the reasons why a community may have poor people but may not have beggars (p. 64).

Ezenweke and Nwadialor scratched on a very important aspect of the Igbo socio-economic life. But within the disposition of Ikeoha consciousness, it is good to understand the Igbo concepts of 'Ure', 'Utoro' or 'Ngala'. The transliteration for these words could be 'Brag', 'Braggadocio' 'Pride', 'Swagger' or even 'Puff'. For 
others outside the Igbo disposition, these states of being may make little or no sense but for the Igbo, they are worth dying for. Ndiigbo know that whatever wealth he/she accumulates or power he/she appropriates, it is the community and its members who are de facto beneficiaries; the Igbo person who thus accumulated or appropriated relishes only on 'Ure', 'Utoro' or 'Ngala'. It will not be surprising then why the Igbo person in a life-career will seem to aim at taking a title as an accolade upon which hang the summation of his/her achievements and accomplishments. All he/she gets or cares to get out of the whole of life's struggle is the feelings aroused at the mention of that title. This is why denying $\mathrm{him} /$ her titles would be equivalent to making nonsense of all the achievements and accomplishments.

In a further stride, it is important to note that the Igbo word 'Ogaranya' would rather transliterate to 'accomplished' or 'privileged'; it is not 'the wealthy' or 'money bag' as the contemporary Igbo may impress. Among the Northern Igbo of Nsukka, Enugu and Abakaliki, this idea is still retained in everyday Igbo language and in that clime, the accomplished person must be of advanced age and moral good standing with the community; while among the southern people especially Anambra and parts of Imo and Abia States the corrupt version of 'a wealthy person' sways the day-to-day usage of the word. Whereas originally in that clime it meant a person (of whatever age) whose both parents are still alive. Notably, the word 'Ogaranya' has become a corollary to money-making; an interpretation which has affected the morality of wealth creation. Either way, the Igbo proverb "Ogaranyabuomumeomume, anaghiabuogaranyaabu" (Accomplishment is not about what one becomes but that which is demonstrated and demonstrable) holds true. Ultimately, Ogaranya is measured by the quality and extent of one's connectedness to the 
life of the community. This connectedness may be via ones material accomplishments, thereby making the community the prime beneficiary of such accomplishments. Putting all these ideas together, what is meant is that the accomplished person ultimately aims at demonstrating or 'showing-off' his/her accomplishments which could also be in charity, philanthropy or any show of strength to be seen, upheld and hailed by the community and then only relish on 'Ure', 'Utoro' or 'Ngala', the symbolization of which is title-taking. Being conferred a title in the Igbo community is to be decorated with the accolade of a "bragging right" known as "Utoro, Ure or Ngala"; the feeling that go with the braggadocio is the only thing that reverts to the individual.

The concrete benefits of these accomplishments revert to members of the community whose only contribution is to acknowledge, appreciate and hail the 'Achiever' at any given opportunity. Therefore, in the traditional setting, the accomplished achiever within the struggles, carries on his/her shoulders the burden, cares and worries of the community. It is, in fact these which propel and strengthen his/her resolve to embark upon and sustain within the struggle; even when he/she is alone in the struggle, his/her personality is 'We' because even then he/she is 'being-with'.

\section{Ikeotuonye Social-Existential Force}

"Otuonye" is characterized by individualism, a characterization that is not African, nay Igbo. One Igbo proverb says: "Ukwuotuonyeanaghiasambara" (the feet of an individual is not extensive). Extensiveness is measured by connections especially by blood and Ndiigbo attach a lot importance to it. Ikeotuonye refers to the individual who constituted a squad (individualized effort) in the quest for Oganihu Ndiigbo. It impresses the shutting 
down on the 'another-consciousness' to become an isolated existence especially considering others as mere instruments and avenues to that individual's accomplishments. "Oha" and "Otuonye" are rife with positional polarity, oppositional forces and dimensional duality. However, Ikeotuonye is undeniably the existential force which pervaded the Igbo world during the Nigerian civil war in which Ndiigbo were circumvented with the deadliest inventions of humankind as at the time.

The struggle for survival amidst a genocidal barricade and mortal hunger that seduced the Igbo spirit away, Ndiigbo tarried at the brinks of disconnecting from the force of 'Ikeoha'. The postwar situation of Ndiigbo is, as should be expected, informed by the experience of the war which demeaned and injured their psychological and material appreciation of that community which gave meaning to their existence; a community which was ravaged with cruelty, its members wooed by little portions of food compromised the essence of their existence, the industry and ingenuity of its members repudiated, destroyed and confiscated by brutal mediocre class that was far below their cultivated development and civilization. Surviving the inhumanity of the rest of the country and the genocide named war dominated the Igbo consciousness during the war; and decades after that war Ndiigbo are still engaged in that task. This is so because the refusal of Nigeria to rehabilitate, reintegrate and reconcile Ndiigbo, seconded by the socio-economic weapon of tactical impoverishment left the Igbo consciousness programmed with one instinct - survival.

In the first place, the Federal Government headed by Yakubu Gowon had impressed that the war was neither lost nor won by either of the divides in his "No Victor; No Vanquished" slogan and promised the three R's (Reconciliation, Rehabilitation and Reconstruction). Yet for decades there has been more than 
enough evidence to show that Ndiigbo regarded as a defeated race deserve no more than the place of a second fiddle in the Nigerian polity whereas the three R's were nothing more than lip service paid to those defeated people to keep them in check. In the second place, measures were technically put in place to impoverish Ndiigbo; their properties in major Nigerian cities were termed "Abandoned" and handed over to anyone deemed fit by the Federal or regional Government before their very eyes and only twenty pounds was offered to anyone who came along to surrender the more qualitative Biafran currency; not many got even that twenty pounds. Uwalaka (2003) avers that the war continued by other means.

Even though physical formal war did end, yet there appears to have been more insidious more perfidious, more destructive and dangerous war against the Igbos, which have been classically called "the Igbo question" in Nigeria. This is a "war" against the people's psyche, against the people's self identity and self-worth; a war against the people's self-consciousness, a war against the people's economic welfare, symbolized in the now widely used word marginalization (p. 19).

Evidently Ndiigbo have been dubbed one of the most resilient and dogged race in the world and in this circumstance, they did not give up because even in spite of these conditions, they must survive. But this survival is characterized by a tacit conviction that Ndiigbo have a reserved position not only in the Nigerian affairs but also in human affairs; the same poignancy that sustained them for thirty months fighting the arsenic monstrosity of Russia, Germany, Britain and USA in the name of Nigeria. Once the war has succeeded in devastating the Igbo community stronghold, the 
individual emerged who without the concrete feel of the community still bore it in his/her consciousness. Consequently, the fight for the survival of Ndiigbo fell into the hand of the individuals who immediately assumed Messiah-figures to redeem the already bad situation. This task drove Ndiigbo with the same passion that gave them astonishing victory over federal troops at the beginning of the civil war. As many as there were the selfmade Messiahs, so intense was the conflict that inflicted more wounds on the already injured community consciousness.

Coming from the nook and crannies of Igbo land, Ndiigbo dispersed to all parts of the globe in search of means to re-adjust the boundaries of poverty into which they have been schemed; no thanks to the federal government and their trusted advisers. Armed with the internal distrust bred by the various propagandist techniques used against them during the war, Ndiigbo evolved a generation motivated by the existential force of Ikeotuonye. This generation offered varieties of solutions to the Igbo quest for Oganihu; sometimes conflicting ones. However, in these circumstances each struggled for the good of all propelled by the desire to be the author of the solution most sought by Ndiigbo. In fact, the dialectics of the desire to find the ultimate solution to the post-war situation of Ndiigbo and the unwillingness of the selfdetermined finders to accept solutions as coming from another gave rise to the synthesis of Ikeotuonye. Nevertheless, the PanIgbo consciousness and existential force of Ikeotuonye was not set against Ikeoha because the common beneficiary of both is Ndiigbo.

Furthermore, whether Ikeoha or Ikeotuonye, it is Ure,Utoro or Ngala that the Igbo person seeks beyond individual accomplishment. Therefore, even within the drive of Ikeotuonye, it is Ure, Utoro or Ngala which reverts to Otuonye after 
accomplishment whereas the benefits of his/her struggles become the possession of Ndiigbo.

\section{The Dialectics of the Social-Existential Forces of Ikeoha and Ikeotuonye}

The conceptual content of Ikeoha and Ikeotuonye are diametrically opposed. The numerical content of Oha contains Otuonye as its minutest value; that gives insight into the numerical variance between the two. Yet the present writer asserts that in the course of Oganihu Ndiigbo it is neither the conceptual incompatibility of Ikeoha and Ikeotuonye nor the numerical variation of Oha and Otuonye but the Pan-Igbo unity of their purpose and content. In other words, as far as Oganihu Ndiigbo is concerned, Ikeoha and Ikeotuonye are complementary parts of one consciousness or force. This position is in tandem with the idea of Ekwuru (1999):

...the traditional Igbo notion of "force" as the essence of being, has a dual characteristic which could be better designated as the "two-ness principle of reality." A type of paradigmatic duality of complementarity underlies the Igbo concept of being. The polarity of "force" as the essential characteristic of being is not seen to be contradictory but complementary (p. 61).

The Ikeotuonye socio-economic individualist consciousness did not rise over against Ikeoha altruistic communalist consciousness. Ikeotuonye came to the rescue of Ikeoha as an alternate consciousness to keep the Igbo mind on the track of Oganihu Ndiigbo in terms of furtherance and perpetuation of the race. It is important to note that prosperity and wealth is a craving in every Igbo person. This has often been misunderstood as "love for money" which many have used to taunt Ndiigbo; even some Igbo 
seem to ascribe to this idea. When the heart of the Igbo is set upon creating wealth or prosperity, he passionately stops at nothing to get to the height of it. This drive which has severally been interpreted as greed is ultimately aimed at the good (Oganihu/Odimma) of the Igbo (Ndiigbo). Contemporary and sworn Igbo hater Mohammed (2014) had impugned: "Igbo remains one ethnic group in Nigeria that is so devoid of any shame to show their greed, selfishness and contempt for other ethnic groups."

Junaid Mohamed who represented Kano State in the 2014 National Conference made this judgement with unrepentant impunity against the backdrop that the Igbo were virtually Nigeria's economic henchmen; controlling, according to him, $42 \%$ of the nations key economic positions and the age long hunch borne by Ndiigbo as a result of the January 1966 coup which saw to the killing of key political players in the Northern and SouthWestern parts of the country. Be that as it may, Mohammed is judging a situation he does not understand. The political and economic points scored by Ndiigbo in Nigeria are unprecedented given their post-war situation and the subtle scheme that sought to keep them perpetually below the poverty line.

Mohammed is witnessing to the successful effect of Ikeotuonye existential force which radicalized the zest of Ndiigbo to assert themselves as principal players in the Nigerian social, economic and political milieu. Critics like Kolawole (2011) should understand that Ndiigbo are not more desperate about the most coveted presidential seat than they are keen in attaining positions that will foster the Igbo cause (Oganihu Ndiigbo). Nigeria is a typical area for the display of the Igbo proverb 'Nwatatikariaibeyan'aki, akpooyaonyeanyaukwu' (If a youngster outwits another in an endeavour, he/she will be tagged 'greedy'). Moreover, the natural egalitarian environment of Ndiigbo sustains 
and encourages competitiveness and every Igbo goes to this competition always ready because that seems to be the constant dialectics of life itself. It is then understood why the force of Ikeotuonye could be sustained in the midst of the mortal attack on Igbo corporate existence but it may not be misunderstood as the exile of that Pan-Igbo consciousness of Oganihu Ndiigbo especially by Ndiigbo themselves.

Many present day Igbo would inadvertently impress that the Igbo are lacking in trust, love and unity; they may even as much as impress that Igbo hate each other. Notably, most times sentiments of this sort are raised to evaluate the prevailing atmosphere around a single Igbo person who sets his heart on a goal of self improvement, drives it with such focus and energy that seem to dwarf every contending opposition. Even at that, Oganihu Ndiigbo is that ultimate goal; a Pan-Igbo sentiment and everyday Igbo is caught within the web of its influence and drive. Be that as it may, the impression of the lack of trust, love and unity has been identified as a post-war experience and its dynamics need to be understood to be well situated.

The experience of the Nigerian civil war is not a thing that the Igbo will overcome in a hurry. Quite a number of patterns in the contemporary Igbo behavior and outlook towards life have identified as consequences of the experience of the Nigerian civil war. Significantly, the struggle for the survival; furtherance and perpetuation of the Igbo race is the war and post-war dimension in the Oganihu Ndiigbo consciousness; prior to the experience of that war it is the sustenance and maintenance of the race that dominated that consciousness. In lieu of this, the present writer identified two epochs in the development of Oganihu Ndiigbo consciousness characterized by Ikeoha and Ikeotuonye. 


\section{Conclusion}

Oganihu Ndiigbo is not and can never be an abandoned project as many Igbo lovers, leaders and detractors fear. This paper understood that quest, desire and passion as a mortal drive, undying consciousness and existential force in every Igbo-bu-Igbo.

The paper brought in the beauty of interpretation and its crucial role in shaping the life and molding the thought-pattern of human beings. This is not an exercise in re-branding but a reinterpretation of issues in Igbo existential reality which have so far been given derogatory interpretations. At the same time the work was not set to undermine the traditional morals and values of Igbo culture within the morass of clandestine, nefarious and pervasive activities that many Ndiigbo engage in, in order to make money. It rather seeks to re-establish the traditional understanding of concepts like Ogaranya in relation to Oganihu Ndiigbo so as to refocus Onyeigbo to the purpose of creating wealth and creating it in ways that does not contradict the existential force and synthesis of this dialectics; it has moral extensions that agree with the Igbo spirit which demands responsibility from seekers of Oganihu Ndiigbo. Onyeigbo (Igbo person) is not a name one bears in Nigeria and all over the world with ease.

Everywhere in this country, different tribes refer to the Igbo with one derogatory name or another which is aimed at passing bad feelings about Ndiigbo wherever they may be found. As other tribes create, harness and disseminate these negative feelings about Ndiigbo, some Igbo themselves wittingly or unwittingly accept this judgment and understand their folks as such. Every Onyeigbo will not be doing Ndiigbo any good if he/she allows this thought pattern to hold him/her captive. To achieve OganihuNdiigbo, Ndiigbo themselves will have to take the lead eliciting a positively driven consciousness within the status quo. Ndiigbo are found everywhere 
in the world including areas very hostile to human life. Somehow it is in the consciousness of the Igbo that the home front is not a place to be if one really wants to make a meaningful progress in life. Ndiigbo may be held under the sway of Kolawole's double theory of Conspiracy and Enemy within if the kind of input made by this work is not supported and explored.

Conspiracy may also be understood as external aggression. This has to do with the misconstruance, by non-Igbo, of any action or exhibition of character of Ndiigbo. It is the likes of this misconstruance which has led many to think Ndiigbo as greedy, foolhardy, dangerous, criminal-minded, arrogant, ungovernable and so forth, thereby justifying any attack on their persons or property. The consequence of this is that Ndiigbo will not be free and secure outside Igbo land. On the other hand, Enemy-within also understood as shooting oneself in the leg; having to do with the convictions of some Ndiigbo that these aforementioned judgments about Ndiigbo are correct. The consequence is that the home front will be insecure; rife with suspicion, fear and anarchy. A lot of hostilities and insecurity especially kidnapping which bedevils the South-Eastern path of Nigeria (the home front of Ndiigbo) is as a result of this mentality. Security reports emanating from investigated cases show that there is no singular case of kidnapping where an insider, possibly a family member, is not a principal player.

Most of those who engage in such criminalities are surely victims of wrong interpretation of the existential force of Ikeotuonye. It is important to note the two concepts introduced in this work - Ure, Utoro and Ngala - as the end of Igbo struggles. With this understanding, every Onyeigbo should know that he/she is a beneficiary of the accomplishments of another Onyeigbo whose only reward is Ure, Utoro and Ngala. Every Onyeigbo 
conscious of the egalitarian socio-economic sphere of the Igbo world should relish on that opportunity to put in his/her best in the struggle for Oganihu Ndiigbo. Like the woman of Chinua Achebe's No Longer at Ease referred to Okonkwo's car as "Our car" so should it not be lost to the Igbo consciousness that the accomplishments of any Onyeigbo is "Our accomplishments" which ultimately reverts to Oganihu Ndiigbo.

Chika J.B.G. Okpalike

Department of Religion and

Human Relations

Nnamdi Azikiwe University,

Awka

cg.okpalike@unizik.edu.ng

\section{References}

Abasika, E. T. M. (1993). The Conspiracy and the World's Best Kept Secret. Ibadan: Intes Printers Limited.

Adujie, P. I. (2011). "Igbo Marginalized, Relegated and Bashed Endlessly!" Retrieved March 15, 2013. From http://www.igbofocus.co.uk/html/ndi_igbo.html.

Ekwuru, E. G. (1999). The Pangs of an African Culture in Travail. Owerri: Totan.

Eteng, I. A. (2002). "Igbo Community Development and Social Welfare”. In G. E. K. Ofomata (ed). A Survey of the Igbo Nation. Onitsha: Africana First.

Ezeani E. (2013). In Biafra Africa Died: A Diplomatic Plot. London: Veritas Lumen. 
Ezenweke, E. O. and Nwadialor, K. L. (2013). "Understanding Human Relations in African Traditional Religious Context in the Face of Globalization: Nigerian Perspectives". American International Journal of Contemporary Research Vol. 3 No. 2, Pp. $61-70$.

Ilona, R. (2007). The Igbos: Jews in Africa. Abuja: Counsellor International.

Kolawole, S. (2011). "Ndigbo in the Fourth Republic". Retrieved October 9, 2014.2 From http://www.thisdaylive.com/articles/ndigbo-in-the-fourthrepublic/85573/

Madu, L. (2012). "The Igbo People of Nigeria - Jews of Africa". Retrieved March 17, 2013. From http://thewillnigeria.com/opinion/17244.html

Muhammed, J. (2004) "Igbos Are A Shameless Ethnic Group With "Greed, Selfishness" Retrieved November 10, 2014. Fromhttp://abusidiqu.com/igbos-shameless-ethnic-groupgreed-selfishness-junaid-muhammed/.

Odimegwu, I. (2007). "African Communalism and the Search for African Personhood". In Ike Odimegwu (ed). Perspectives on Communalism. Canada: Trafford.

Okolo, C. B. (1993). What is to be African? Enugu: CECTA.

Onunwa, U. R. (2005). Studies in Igbo Traditional Religion. Obosi: Pacific.

Onwubiko, O.A. (1991). African Thought, Religion and Culture. Enugu: SNAAP.

Onyewuenyi, I. C. (2002). "Igbo (African) Philosophy". In G. E. K. Ofomata (ed). A Survey of the Igbo Nation. Onitsha: Africana First.

Osuji, O. T. (2008). “Was Olaudah Equiano Igbo?" Retrieved $\begin{array}{lll}\text { March 20, 2013. } & \text { From }\end{array}$ 
http:/chatafrik.com/articles/american-affairs/item/441-wasolaudah-equiano-igbo?.html

Rosen, B. (2012). "On the Igbo, Teshuvah and the Resilience of the Jewish spirit". Retrieved March 17, 2013. From http://www.kulanu.org/nigeria/spirit.php

Uwalaka, J. (2003). The Struggle for an Inclusive Nigeria: Igbos to be or not to be - A Treatise on Igbo Political Personality and Survival in Nigeria. Enugu: SNAAP.

Uzukwu, E.E. (1996). A listening church: Autonomy and communion in African churches. New York: Orbis 